\title{
ANALISIS PERUBAHAN LUASAN TERUMBU KARANG DENGAN MENGGUNAKAN DATA PENGINDERAAN JAUH CITRA LANDSAT 7 ETM+ DAN 8 OLI DI PERAIRAN PULAU MENJANGAN KECIL KARIMUNJAWA (JEPARA)
}

\author{
Analysis Area Changes of Coral Reefs using Remote Sensing Data Landsat 7 ETM + and 8 OLI in the waters of \\ Menjangan Kecil Island, Karimun Jawa (Jepara)
}

\author{
Muhammad Ilham, Supriharyono*) dan Niniek Widyorini \\ Program Studi Manajemen Sumberdaya Perairan, Departemen Sumberdaya Akuatik \\ Fakultas Perikanan dan Ilmu Kelautan, Universitas Diponegoro \\ J1. Prof. Soedharto, SH, Tembalang, Semarang, Jawa Tengah - 50275, Telp/Fax. +6224 7474698

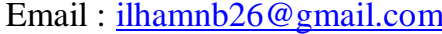

\begin{abstract}
ABSTRAK
Ekosistem terumbu karang menjadi salah satu potensi sumberdaya pesisir yang memiliki banyak manfaat bagi lingkungan sekitar. Pulau Menjangan Kecil merupakan salah satu pulau di Karimunjawa yang memiliki ekosistem terumbu karang. Beraneka ragam ekosistem terumbu karang yang ada, menjadikan pulau ini sebagai salah satu destinasi wisata yang menarik untuk wisatawan. Penelitian dilaksanakan pada Bulan September 2017. Penelitian bertujuan untuk mengetahui kondisi terumbu karang ditinjau dari nilai persentase luasam penutupan terumbu karang, tingkat akurasi penggunaan citra Landsat 7 ETM+ dan 8 OLI tahun 2013, 2015, dan 2017. Sampling dilakukan pada empat titik. Metode yang digunakan Line Transect, Lyzenga Transformation dan Confusion Matrix. Hasil penelitian menunjukkan bahwa persentase tutupan luasan terumbu karang sebesar $54,31 \%$, perubahan luasan terumbu karang berkurang sebesar 14,1 Ha (3,2\%), uji akurasi citra satelit yang dihasilkan sebesar $86,95 \%$.
\end{abstract}

Kata Kunci : Citra Satelit, Confusion Matrix, Lyzenga Transformation, Perubahan Luasan, Pulau Menjangan Kecil, Terumbu Karang, Uji Akurasi

\begin{abstract}
Coral reef ecosystems become one of the potential of coastal resources that have many benefits for the surrounding environment. Menjangan Kecil Island is one of the islands in Karimunjawa which has coral reef ecosystem. A wide range of coral reef ecosystems, making this island as one of the tourist destinations to attract tourists. The research was conducted in September 2017. The objectives of this study were to determine the condition of coral reefs from the percentage of coral cover coverage, the accuracy of Landsat 7 ETM + and 8 OLI imagery in 2013, 2015 and 2017. Sampling was conducted on four stations. The method used is Line Transect, Lyzenga Transformation and Confusion Matrix. The results showed that the percentage of coral cover cover was $54,31 \%$, the coral reef area decreased by 14,1 Ha (3,2\%), the test of satellite image accuracy was $86,95 \%$.
\end{abstract}

Keyword : Accuracy Test, Area Cover Change, Confusion Matrix, Coral Reef, Lyzenga Transformation, Remote Sensing, Small Menjangan Island

*) Penulis Penanggungjawab

\section{PENDAHULUAN}

Terumbu karang merupakan salah satu ekosistem yang berada di wilayah pesisir. Ekosistem yang merupakan satu potensi sumberdaya perairan di Indonesia ini memiliki banyak manfaat bagi lingkungan. Selain bermanfaat bagi biota laut, ekosistem terumbu karang sering dimanfaatkan oleh masyarakat sebagai tujuan wisata. Menurut Aini (2013), Terumbu karang merupakan salah satu potensi sumberdaya perairan yang melimpah di Indonesia. Indonesia menempati peringkat teratas untuk luas dan kekayaan jenis terumbu karang. Terumbu karang berfungsi sebagai tempat hidup berbagai jenis biota laut dan sebagai tujuan pariwisata oleh masyarakat. Menjangan Kecil merupakan salah satu pulau yang memiliki ekosistem terumbu karang. Wilayah ini memiliki persentase tutupan karang hidup yang cukup tinggi dengan nilai yaitu 59,51\%. Hal tersebut menunjukan kondisi terumbu karang tergolong dalam kategori keadaan yang baik, dengan rentan 51\% - 70\% (Anonim,2014). Terumbu karang yang berada di Menjangan Kecil beberapa bagian besar mengalami kerusakan 
ekosistem akibat dari pemanfaatan sumberdaya yang tidak ramah lingkungan dan juga cukup berlebihan. Hal lain juga dipengaruhi faktor lain yaitu faktor alami yang membuat keadaan terumbu karang yang berada di Menjangan Kecil mengalami penurunan kondisi terumbu karang setiap tahunnya.

Permasalahan utama yang saat ini dihadapi pesisir Pulau Menjangan Kecil adalah belum ada informasi mengenai kondisi dan perubahan luasan terumbu karang. Usaha yang dilakukan untuk memperoleh informasi mengenai kondisi ekosistem terumbu karang yaitu dengan melakukan penelitian yang meliputi presetase penutupan dan perubahan luas.

Tujuan dari penelitian ini adalah :

1. Mengetahui kondisi terumbu karang berdasarkan nilai persentase penutupan terumbu karang hidup di kawasan perairan Pulau Menjangan Kecil, Kepulauan Karimunjawa

2. Mengetahui perubahan luasan terumbu karang di kawasan perairan Pulau Menjangan Kecil, Kepulauan Karimunjawa menggunakan citra Landsat

3. Mengetahui tingkat akurasi penggunaan citra Landsat 7 ETM+ dan 8 OLI dalam penginderaan jauh terumbu karang di kawasan perairan Pulau Menjangan Kecil, Kepulauan Karimunjawa

\section{MATERI DAN METODE PENELITIAN}

Pengambilan sampel dilakukan pada empat titik yang jumlahnya ditentukan dengan metode eksploratif, yaitu dilakukan dengan mencari informasi untuk memberikan gambaran yang berkaitan dengan materi penelitian. Pada masing-masing titik dilakukan pengamatan dengan cara mencatat bentuk pertumbuhan karang, yang ditemukan di sepanjang transek garis pada daerah rataan terumbu. Pengamatan ekosistem terumbu karang dengan menggunakan metode Line Transect. Hal ini diperkuat oleh Aini (2013), pengukuran penutupan terumbu karang adalah untuk melihat gambaran luasan karang hidup dan menggunakan metode line transek dengan memasang line transek sepanjang 50 meter yang sejajar garis pantai.

Pengukuran ekosistem terumbu karang meliputi pengukuran persentase penutupan karang dengan menggunakan rumus. Selanjutnya hasil yang didapat dari perhitungan akan dianalisa menggunakan kisaran tingkat persentase karang hidup. Perubahan luasan ekosistem terumbu karang dianalisa dengan pengolahan data citra menggunakan bantuan perangkat lunak ER Mapper 7. Pengukuran tingkat akurasi penggunaan citra Landsat 7 ETM+ dan 8 OLI dalam penginderaan jauh terumbu karang menggunakan confution matrix. Menurut Damayanti (2012), uji akurasi dilakukan terhadap kelompok piksel yang mewakili objek tertentu yang diambil sebagai sampel dalam suatu poligon objek dengan kooordinat lokasi yang sama di lapangan. Selanjutnya sampel yang telah diambil dari lapangan dibandingkan dengan piksel hasil klasifikasi.

\section{HASIL DAN PEMBAHASAN}

\section{Kondisi Umum Lokasi}

Pulau Menjangan Kecil adalah salah satu pulau yang berada di Kecamatan Karimunjawa dan secara geografis terletak di titik koordinat 05053'10" - 05053'50" Lintang Selatan dan 110²6’55” - 110029'36 Bujur Timur. Pulau Menjangan Kecil berdekatan dengan Pulau Menjangan besar dan Pulau Karimunjawa atau tepatnya di sisi sebelah selatan kedua Pulau tersebut. Pulau Menjangan Kecil dipisahkan oleh selat yang dapat ditempuh hanya dalam waktu 30 menit. Pulau Menjangan Kecil merupakan pulau yang tidak berpenduduk tetapi terdapat resort untuk menginap para wisatawan maupun peneliti. dengan luas 43,025 Ha . Pulau ini menjadi sering didatangi oleh wisatawan (Anonim, 2014). Penentuan lokasi sampling mengacu pada pengolahan data dasar pada Landsat 8. Sampling dilakukan pada 4 titik penelitian.

\section{a. Kualitas Air Terumbu Karang}

Hasil pengamatan pada parameter fisika dan kimia di perairan Pulau Menjangan Kecil Taman Nasional Karimunjawa tersaji pada Table 1.

Tabel 1. Pengukuran Parameter Fisika dan Kimia Perairan

\begin{tabular}{|c|c|c|c|c|c|c|c|}
\hline \multirow{2}{*}{ No. } & \multirow{2}{*}{ Parameter } & \multicolumn{4}{|c|}{ Kisaran Hasil pada Titik } & \multirow{2}{*}{$\begin{array}{c}\text { Faktor } \\
\text { Pembatas }\end{array}$} & \multirow{2}{*}{ Daftar Pustaka } \\
\hline & & 1 & 2 & 3 & 4 & & \\
\hline 1. & Salinitas $(\% / 00)$ & 34,6 & 34,6 & 34,8 & 34,7 & $33-34$ & $\begin{array}{c}\text { (Keputusan Menteri } \\
\text { Lingkungan Hidup, No } \\
51,2004)\end{array}$ \\
\hline 2. & Suhu $\left({ }^{0} \mathrm{C}\right)$ & 28,5 & 28,8 & 28,9 & 29 & $28-30$ & $\begin{array}{c}\text { (Keputusan Menteri } \\
\text { Lingkungan Hidup No 51, } \\
\text { 2004) }\end{array}$ \\
\hline
\end{tabular}


Dilakukan pengambilan sample yaitu suhu, pada kedalaman $5-7 \mathrm{~m}$. pada siang hari dan hasil pengambilan data dari parameter suhu pada 4 titik tersebut diperoleh nilai sebesar $28,5-29{ }^{\circ} \mathrm{C}$. terlihat bahwa hasil pengukuran suhu termasuk dalam nilai optimal pertumbuhan karang sesuai dengan Keputusan Menteri Lingkungan Hidup, No 51, (2004) yang berkisar antara $28-30{ }^{\circ} \mathrm{C}$. Tetapi dalam keberlangsungan hidupnya terumbu karang dapat mentoleransi suhu dengan kisaran antara $36-40{ }^{\circ} \mathrm{C}$ (Nyabkken,1998 dalam Aini, 2013). Illahude dan Liasaputra, (1980) dalam Souhoka, (2013) adanya variasi suhu perairan tropic tergolong wajar apabila nilainya berkisar antara $25,6-32,3{ }^{\circ} \mathrm{C}$.

Pada parameter kimia dipilih salinitas sebagai salah satu faktor pembatas bagi karang, dari hasil pengambilan data lapangan salinitas yang didapat pada titik 1 sampai titik 4 yaitu 34,6 - 34,8\% \%enurut Kinsman (1964) dalam Supriharyono (2007) menyatakan, binatang karang hidup subur pada kisaran salinitas antara 34-36 \% . Namun Pengaruh salinitas terhadap kehidupan karang sangat bervariasi tergantung pada kondisi perairan laut sekitar dan pengaruh alam seperti hujan. Berdasarkan angka toleransi tersebut, dapat dikatakan daerah penelitian dalam keadaan yang baik, yang memungkinkan biota karang dan simbionnya dapat hidup atau tumbuh optimal.

\section{b. Persentase Penutupan dan Bentuk Pertumbuhan Karang}

\section{b.1. Persentase Penutupan Karang}

Hasil penutupan karang didapatkan hasil berupa persentase penutupan karang di Pulau Menjangan Kecil Taman Nasional Karimunjawa tersaji dalam Tabel 2 yang kemudian digambarkan sebarannya dalam Gambar 1.

Tabel 2. Hasil Presentase Penutupan Terumbu Karang

\begin{tabular}{|c|c|c|c|c|c|}
\hline \multirow{2}{*}{ No. } & \multirow{2}{*}{ Jenis Tutupan } & \multicolumn{4}{|c|}{ Titik } \\
\hline & & 1 & 2 & 3 & 4 \\
\hline 1. & Karang Hidup & $51,44 \%$ & $54,50 \%$ & $57,50 \%$ & $53,80 \%$ \\
\hline 2. & Karang Mati & $13,11 \%$ & $25,50 \%$ & $13,34 \%$ & $18,82 \%$ \\
\hline 3. & Pecahan karang & $30,33 \%$ & $16,90 \%$ & $29,16 \%$ & $27,38 \%$ \\
\hline 4. & Pasir & $5,11 \%$ & $3,10 \%$ & $0,00 \%$ & $0,00 \%$ \\
\hline & Jumlah & $100 \%$ & $100 \%$ & $100 \%$ & $100 \%$ \\
\hline
\end{tabular}

$70,00 \%$

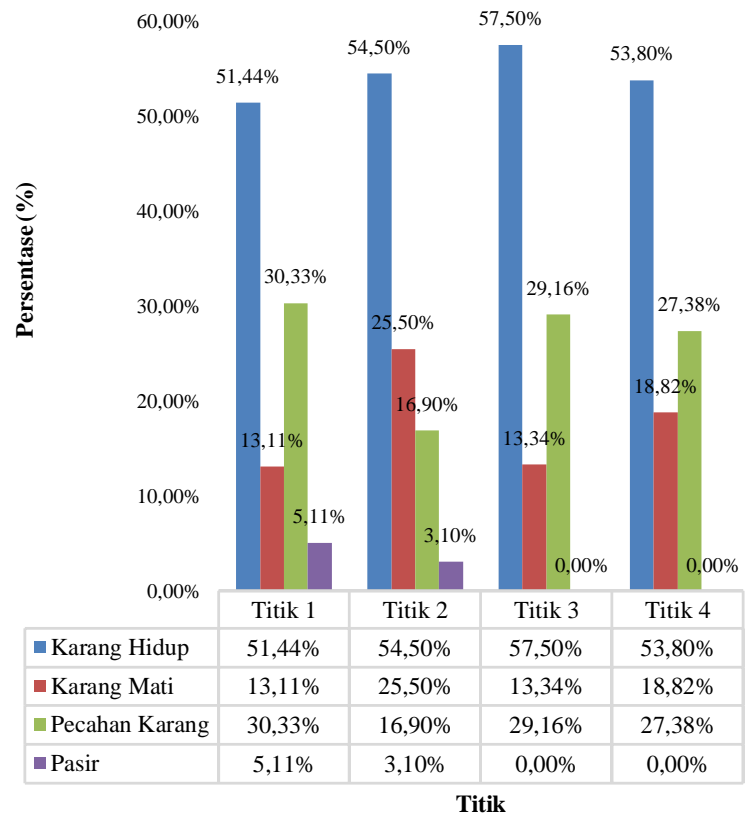

Gambar 1. Grafik Hasil Pengukuran Presentase Penutupan Terumbu Karang

Persentase penutupan karang yang berada di Pulau Menjangan Kecil terbagi menjadi 4 tipe yaitu karang hidup, karang mati, pecahan karang dan pasir. Persentase penutupan karang hidup tertinggi berada pada titik tiga 
hal tersebut kemungkinan di karenakan kondisi lingkungan titik ketiga yang sangat mendukung untuk pertumbuhan karang. Beberapa faktor yang mendukung banyaknya karang hidup di suatu tempat antara lain faktor fisika kimia perairan yang meliputi suhu, salinitas, kedalaman, pH, DO dan arus. Hal tersebut di perkuat oleh Pangaribuan (2013), selain faktor nutrien, pertumbuhan terumbu karang di pengaruhi pula oleh parameter lingkungan. Beberapa parameter lingkungan yang menunjang pertumbuhan terumbu karang yaitu kedalaman, temperature, salinitas, $\mathrm{pH}, \mathrm{DO}$ dan arus.

\section{b.2. Bentuk Pertumbuhan Karang}

Berdasarkan hasil pengamatan bentuk pertumbuhan karang di Pulau Menjangan Kecil Taman Nasional Karimunjawa didapatkan hasil berupa nilai kemunculan yang tersaji pada tabel 3 dibawah ini:

Tabel 3. Bentuk Pertumbuhan Karang

\begin{tabular}{lccccc}
\hline \multirow{2}{*}{ Bentuk Pertumbuhan } & \multicolumn{3}{c}{ Titik } & Rata - rata \\
\cline { 2 - 5 } & 1 & 2 & 3 & 4 & 5,25 \\
\hline Acropora Branching & 4 & 7 & 7 & 3 & 3,5 \\
Acropora Submassive & 7 & 2 & 5 & 0 & 3 \\
Acropora Encrusting & 5 & 1 & 3 & 3 & 0,75 \\
Acropora Digitate & 1 & 2 & 0 & 0 & 0,75 \\
Acropora Tabulate & 2 & 0 & 1 & 0 & 12,75 \\
Coral Branching & 5 & 3 & 20 & 23 & 1 \\
Coral Encrusting & 0 & 0 & 2 & 6 & 14,5 \\
Coral Foliose & 22 & 20 & 10 & 9 & 9,5 \\
Coral Massive & 12 & 7 & 10 &
\end{tabular}

Hasil pengamatan bentuk pertumbuhan karang di pulau Menjangan Kecil menunjukan bahwa didaerah tersebut karang yang nilai kemunculan rata2 paling tinggi oleh karang dengan bentuk pertumbuhan Coral Foliose (CF). Menurut Panjaitan (2012) karang yang berbentuk seperti lembaran daun, warnanya hijau hingga hijau keabuabuan, talusnya berbentuk seperti daun atau yang dikenal dengan foliose. Foliose memiliki struktur seperti daun yang tersusun dengan lobus - lobus dan relative lebih longer melekat pada substratnya. Talusnya datar, lebar, banyak lekukan seperti daun yang mengkerut berputar (Yurnaliza, 2002 dalam Mafazza, 2016).

Coral Foliose (CF) yang berbentuk lembaran-lembaran yang memanjang dan menyerupai bunga biasanya dipengaruhi oleh arus dan kedalaman perairan. Lokasi pengamatan yang memiliki arus yang tenang sangat cocok bagi pertumbuhan karang jenis ini. Hal tersebut diperkuat oleh Suryanti et al. (2011), pada daerah dengan arus kuat banyak dijumpai karang berbentuk pendek, kuat merayap, submassif.

\section{c. Perubahan Luasan Terumbu Karang}

Hasil pengukuran perubahan luasan terumbu karang di Pulau Menjangan Kecil, Taman Nasional Karimunjawa tersaji dalam Tabel 4 yang kemudian digambarkan sebarannya dalam Gambar 2 dan 3.

Tabel 4. Perubahan Luasan Penutupan Karang di Pulau Menjangan Kecil

\begin{tabular}{clcccccccc}
\hline \multirow{2}{*}{ No. } & \multirow{2}{*}{ Tipe Ekosistem } & \multicolumn{2}{c}{ Tahun 2013 } & \multicolumn{2}{c}{ Tahun 2015 } & \multicolumn{2}{c}{ Tahun 2017 } & \multicolumn{2}{c}{ Perubahan } \\
\cline { 3 - 9 } & Ha & $\%$ & Ha & $\%$ & Ha & $\%$ & Ha & $\%$ \\
\hline 1 & Karang Hidup & 43,4 & 31,6 & 33,0 & 21,5 & 29,3 & 20,3 & $-14,1$ & $-3,2$ \\
2 & Karang Mati & 24,0 & 17,5 & 33,8 & 21,9 & 26,0 & 18,1 & 2,0 & 0,4 \\
3 & Pecahan Karang & 26,2 & 19,1 & 34,0 & 22,1 & 39,9 & 27,7 & 13,7 & 3,1 \\
4 & Pasir & 43,7 & 31,8 & 53,0 & 34,5 & 48,7 & 33,9 & 5,0 & 1,1 \\
& Luas Total & 137,3 & 100,0 & 153,8 & 100,0 & 143,8 & 100,0 & & \\
\hline
\end{tabular}




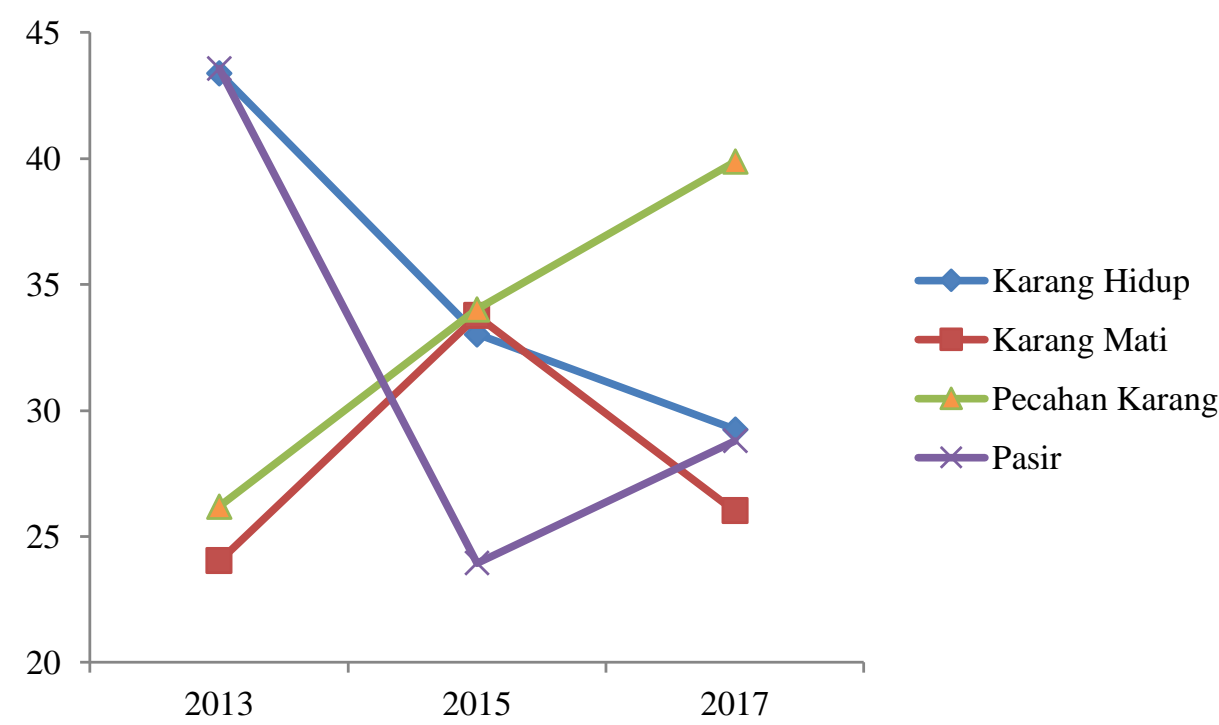

Gambar 2. Grafik Perubahan Luasan Karang Hidup

Berdasarkan gambar 4 terlihat bahwa terjadinya perubahan luasan terumbu karang diduga oleh faktor dari lingkungan yaitu perubahan musim pada tahun 2013 - 2015 yang sangat buruk. Dan juga faktor lain adalah pemutihan karang dan juga kegiatan pariwisata yang tidak ramah lingkungan. National Oceanic and Atmospheric (NOAA) menjelaskan bahwa pada akhir tahun 2015 hingga pertengahan 2016 terjadinya peristiwa El Nino yang menyebabkan naiknya suhu permukaan laut yang berpusat di Samudra Pasifik, sehingga suhu perairan di Indonesia menjadi lebih hangat. Hal ini mengakibatkan memutihnya karang pada sebagian besar lokasi pengamatan Taman Nasional KarimunJawa (Pardede et al.,2016).

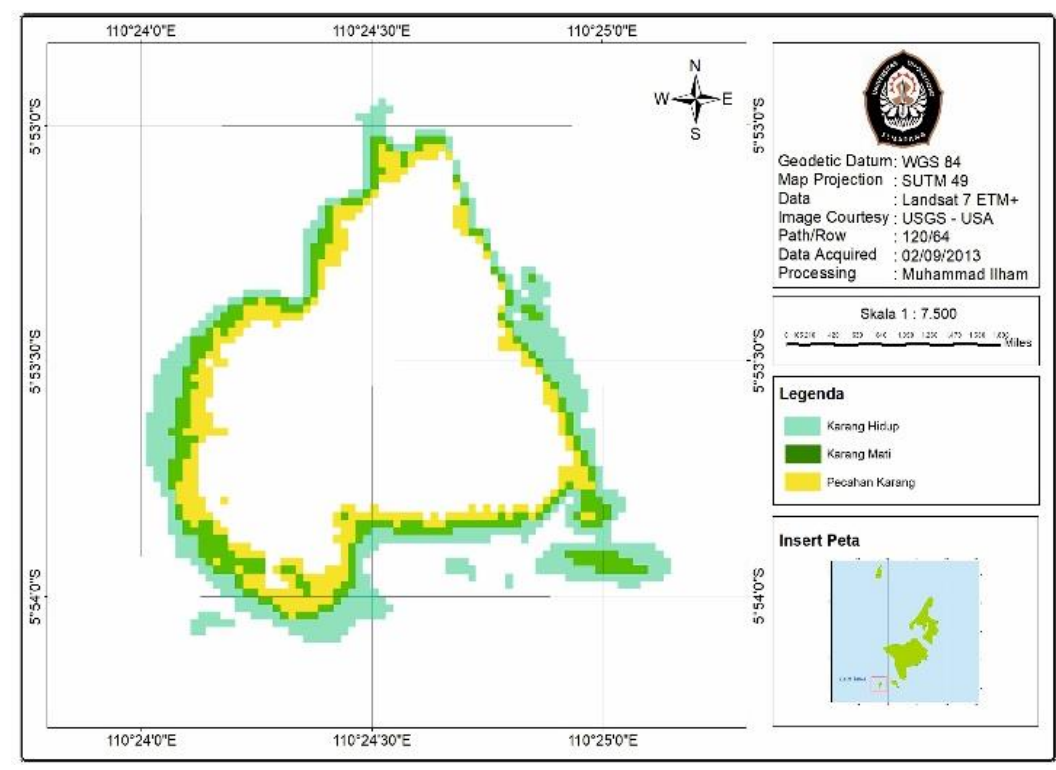

(a) 


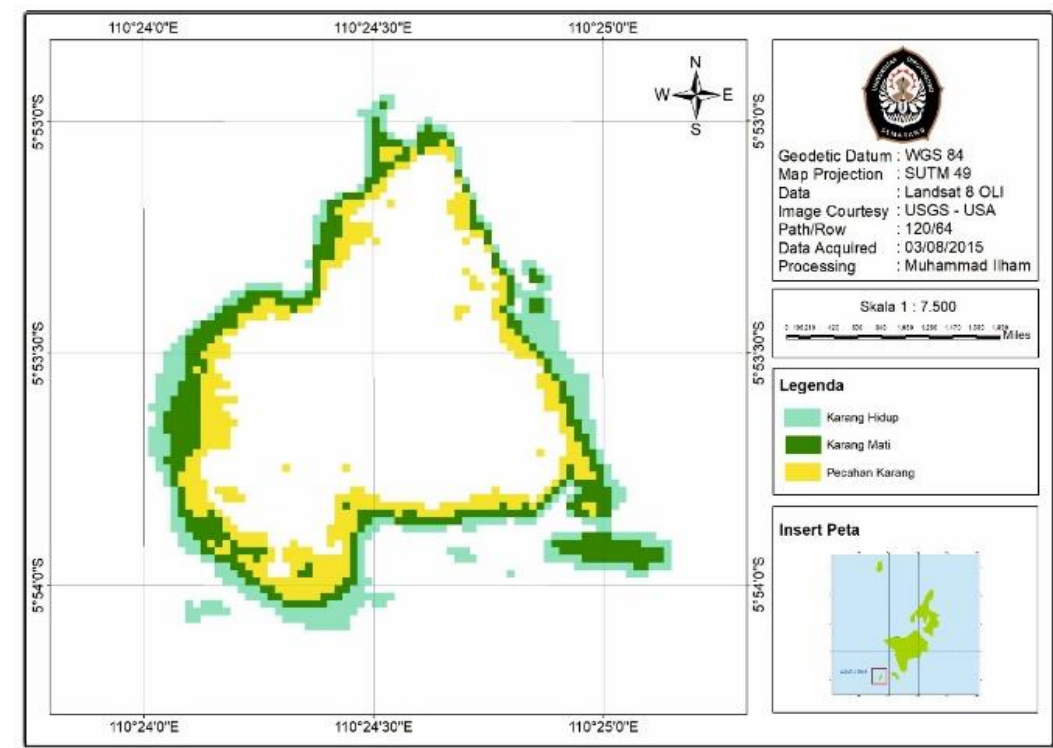

(b)

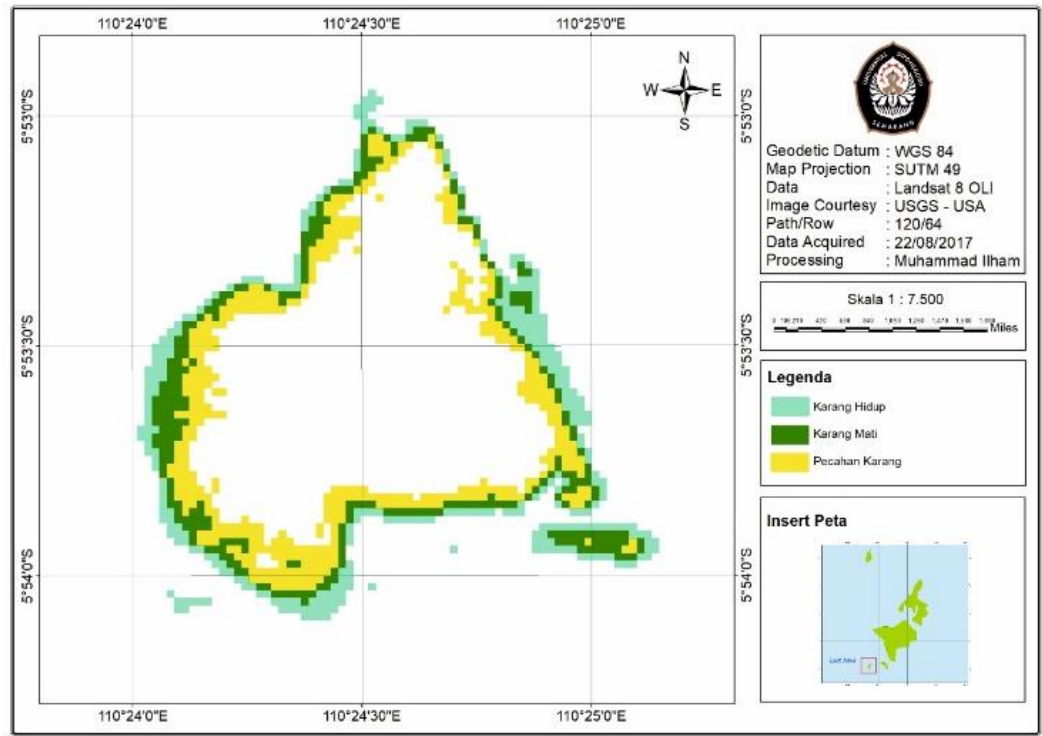

(c)

Gambar 3. Perbandingan Perubahan Luas Terumbu Karang Tahun (a)2013, (b)2015, dan (c)2017

\section{d. Uji Akurasi Penutupan Lahan}

Hasil pengukuran uji akurasi penutupan lahan pada lokasi penelitian di Pulau Menjangan Kecil, Karimunjawa tersaji dalam Tabel 5.

Tabel 5. Uji Akurasi (confusion matriks) di Pulau Menjangan Kecil

\begin{tabular}{|c|c|c|c|c|c|c|c|c|}
\hline \multirow{2}{*}{\multicolumn{2}{|c|}{ Confusion }} & \multirow{2}{*}{ Matriks } & \multicolumn{5}{|c|}{ Data Hasil Lapangan } & \multirow[b]{2}{*}{ Omisi } \\
\hline & & & Karang Hidup & Karang Mati & Pecahan Karang & Pasir & Total & \\
\hline \multirow{7}{*}{ 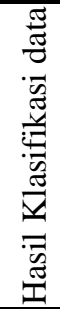 } & \multicolumn{2}{|c|}{ Karang Hidup } & 9 & 0 & 0 & 0 & 9 & 0 \\
\hline & \multicolumn{2}{|c|}{ Karang Mati } & 1 & 2 & 0 & 0 & 3 & 1 \\
\hline & \multicolumn{2}{|c|}{ Pecahan Karang } & 2 & 0 & 4 & 0 & 6 & 2 \\
\hline & \multicolumn{2}{|l|}{ Pasir } & 0 & 0 & 0 & 5 & 5 & 1 \\
\hline & \multicolumn{2}{|l|}{ Total } & 12 & 2 & 4 & 5 & 23 & \\
\hline & \multicolumn{2}{|c|}{ Komisi } & 4 & 0 & 0 & 3 & & \\
\hline & Total D & iagonal & 20 & & & & & \\
\hline
\end{tabular}

${ }^{\oplus}$ Copyright by Management of Aquatic Resources (MAQUARES) 
Pada pengolahan citra ini ke akuratan dari pengolahan citra satelit dilakukan dengan hasil uji akurasi dari 23 titik yang diambil terdapat 3 titik yang tidak sesuai akibat salah satu citra satelit menginterprestasikan data. Pada pengujian akurasi ini terdapat yang namanya komisi dan omisi. Omisi adalah jumlah piksel yang masuk kekelas lain sedangkan komisi adalah jumlah piksel masuk dari kelas lain (Damayanti,2012). Dalam penelitian ini didapatkan nilai uji akurasi sebesar 86,95\%, Menurut Green et al., (2000) dalam Wahiddin et al., (2012), akurasi peta habitat terumbu karang yang dihasilkan dari citra Landsat 7 ETM+ dan 8 OLI menggunakan data pengamatan lapangan sebanyak lima kelas habitat yang mencapai 69\%. Dapat digunakan untuk inventarisasi data ditambahkan pula seluruh kelas yang dihasilkan dari klasifikasi citra maupun sampel training area menunjukan kemampuan yang baik dan dapat digunakan dalam proses pemetaan dan pada nilai $60-80 \%$ direkomendasikan bagi kegiatan inventarisasi untuk pemantauan sumberdaya .

\section{KESIMPULAN}

Kesimpulan yang dapat diperoleh dari penelitian yang telah dilakukan adalah:

1. Status kondisi dari persentase penutupan terumbu karang menggunakan metode LT (Line Transec) di Pulau Menjangan Kecil menghasilkan persentase sebesar 54,31\% tergolong dalam kategori baik.

2. Perubahan luasan habitat terumbu karang yang berkurang sebesar $14,1 \mathrm{Ha}(3,2 \%)$ dari tahun 2013-2017,

3. Uji akurasi yang dihasilkan sebesar $86,95 \%$, hal ini mengartikan bahwa pemetaan terumbu karang menggunakan citra satelit Landsat 7 ETM+ dan 8 OLI dapat memberikan informasi yang cukup mewakili keadaan aslinya.

\section{UCAPAN TERIMAKASIH}

Ucapan terimakasih ditujukan kepada Dr. Ir. Frida Purwanti, M.Sc, Sigit Febrianto, S.Kel, M.Si. dan, Ir. Siti Rudiyanti, M.Si yang telah memberikan saran dan kritik yang sangat bermanfaat bagi penulis. Kepada semua pihak yang telah membantu sehingga penulis dapat menyelesaikan artikel ini.

\section{DAFTAR PUSTAKA}

Aini, M., C. Ain, dan Suryanti. 2013. Profil Kandungan Nitrat Dan Fosfat Pada Polip Karang Acropora Sp. di Pulau Menjangan Kecil Taman Nasional Karimunjawa. Journal of Maquares. 2(4):118-126

Anonim,2014. Menjangan Kecil http://www.ppk-kp3k.kkp.go.id. (diakses pada tanggal 20 Juli 2017)

Damayanti, R. 2012, Pemetaan Terumbu Karang Di Perairan Pulau Tabuhan Kab. Banyuwangi Menggunakan Citra Satelit Quickbird. Madura. Fakultas Pertanian Universitas Trunojoyo.

KEPMENLH. (2004). Keputusan Menteri Negara Lingkungan Hidup No.51 Tentang Baku Mutu Air Laut untuk Biota Laut. Jakarta. Kementerian Lingkungan Hidup, Jakarta, hal:1497.

Pangaribuan, Tumpal H, C. Ain dan P. Soedarsono. 2013. Hubungan Kandungan Nitrat Dan Fosfat Dengan Densitas Zooxanthellae Pada Polip Karang Acropora Sp. Di Perairan Terumbu Karang Pulau Menjangan Kecil. Karimun Jawa. Journal Of Maquares. 4(2):136-145

Souhoka, J. 2013 Kondisi dan Keanekaragaman Karang Batu di Perairan Pulau Gangga Sulawesi Utara. UPT. Loka Konservasi Biota Laut - Lembaga Ilmu Pengetahuan Indonesia Bitung. Indonesian journal of marine sciences. 18(4):213-224

Supriharyono, 2007. Pengelolaan Ekosistem Terumbu Karang. Djambatan. Jakarta. 118 hal.

Suryanti, Supriharyono, Roslinawati Y. 2011. Pengaruh Kedalaman Terhadap Morfologi Karang di Pulau Cemara Kecil, Taman Nasional Karimunjawa. Jurnal Saintek Perikanan 7(1): 63-69

Wahiddin, Nurhalis, Vicentius P.Siregar, Bisman Nababan, Indra Jaya, dan Sam Wouthuyzen. 2014. Deteksi Perubahan Habitat Terumbu Karang Menggunakan Citra Landsat. Morotai. MSP-FPIK Universitas Khairun.

Nybakken, J.W. 1998. Biologi laut: Suatu Pendekatan Ekologi. PT. Gramedia, Jakarta. 458 dalam : Aini 